* Doutor e Mestre em Direito pela PUC/MG. Pós-graduado em Ciências Penais pelo CAD/UGF. Professor do Programa de Pósgraduação stricto sensu em Direito Penal da PUC/MG. Professor de Direito Penal e Processo Penal da $\mathrm{PUC} / \mathrm{MG}$ (graduação e pós-graduação) e do Centro Universitário Unihorizontes. Advogado Criminalista sócio do escritório Ariosvaldo Campos Pires Advogados. E-mail:henriquepenal@ gmail.com.

** Bacharel em Direito. Advogada. E-mail: jgunther. adv@gmail.com

\section{Medida Cautelar Criminal De Recolhimento Domiciliar noturno Cumulado Com O Monitoramento Eletrônico E A Aplicação Da Detração Penal}

\author{
Criminal Precautionary Measures Regarding \\ Night House Arrest Cumulated With Electronic \\ Monitoring And The Application Of Criminal \\ DETRACTION
}

\section{Henrique Viana Pereira* Juliana Günther Fonseca de Mattos**}

Como citar: PEREIRA, Henrique Viana; MATTOS, Juliana Günther Fonseca de. Medida cautelar criminal de recolhimento domiciliar noturno cumulado com o monitoramento eletrônico e a aplicação da detração penal. Revista do Direito Público, Londrina, v. 14, n. 1, p. 65-82, abr. 2019. DOI: 10.5433/1980-511X2019v14n1p65. ISSN: 1980-511X.

Resumo: O presente artigo científico analisa a possibilidade de aplicação do instituto da detração penal face à hipótese do recolhimento domiciliar noturno, cumulado com o monitoramento eletrônico, ambos como medidas cautelares penais. A implementação da Lei $\mathrm{n}^{0} 12.403$, de 04 de maio, de 2011, Lei 12.403/2011, alterou o Código de Processo Penal (CPP) brasileiro, inserindo a possibilidade das medidas cautelares pessoais diversas da prisão (art. 319, do CPP). Diante de uma nova perspectiva no direito processual penal brasileiro, busca-se concluir se é ou não possível aplicar o instituto da detração, para descontar na pena privativa de liberdade imposta ao sentenciado o tempo que ele foi submetido ao recolhimento domiciliar noturno, cumulado ao uso do monitoramento eletrônico.

Palavras-chave: Medida cautelar penal. Recolhimento domiciliar noturno. Monitoramento eletrônico. Detração.

Abstract: This paper analyzes the possibility of applying the institute of detraction in the hypothesis of night house arrest with electronic monitoring as precautionary measures. The implementation of Law no. 12.403/2011 amended the Brazilian Code of Criminal Procedure as it created the possibility of several 
personal precautionary measures of imprisonment. Faced with a new perspective in the brazilian criminal procedural law, this paper questions whether or not it is possible to apply the detraction the custodial sentence imposed on the sentenced in the period in which he or she is submitted to night house arrest and electronic monitoring.

Keywords: Precautionary Measures. Night House Arrest. Electronic Monitoring. Criminal Detraction. 


\section{INTRODUÇÃO}

$\mathrm{O}$ inchaço do aparelho carcerário e a necessidade imperativa de alternativas para o sistema penal tornam as medidas cautelares diversas da prisão uma solução basilar para evitar o encarceramento desnecessário. A aprovação da Lei n 12.403, de 04 de maio, de 2011, Lei de Medidas Cautelares, trouxe uma revisão das regras sobre as cautelares penais e apresentou, no art. 319, do Decreto-Lei n 3.689, de 03 de outubro de 1941 (Código de Processo Penal), dentre outras, a possibilidade do recolhimento domiciliar noturno e do monitoramento eletrônico como medidas distintas à prisão.

Tais medidas podem ser aplicadas cumulativamente e, juntas, configuram hipótese que pode beneficiar a todos. Afinal, desde que devidamente justificada, não ofende a presunção de inocência, porque não "antecipar” a formação da culpa do indivíduo, antes do trânsito em julgado da sentença penal condenatória.

Contudo, o legislador não adequou tais medidas cautelares a institutos já existentes no ordenamento jurídico, especialmente no caso da detração, prevista no art. 42 da Lei $\mathrm{n}^{\mathrm{o}} 2.848$, de 07 de dezembro de 1940 (Código Penal). A detração determina o cômputo, na pena privativa de liberdade, do tempo que o acusado passou em prisão provisória. Todavia, a nova legislação não explicitou a possibilidade de desconto na pena final para os casos em que o acusado for submetido ao recolhimento domiciliar e ao monitoramento eletrônico durante a instrução do processo.

É natural que o acusado que aguardou o andamento processual preso tenha esse tempo descontado da pena final. O recolhimento domiciliar e uso da tornozeleira como medidas cautelares também são graves, pois limitam a liberdade de locomoção, ainda que de forma menos drástica que a prisão preventiva e, portanto, pretende-se verificar o cabimento da detração da pena, ainda que aplicado em diferentes medidas.

O fato de o legislador ter sido omisso em relação a possibilidade da aplicação da detração em face das medidas cautelares diversas da prisão não pode configurar um abuso do "poder-dever" de punir do Estado que, ao evitar tal análise, pode imputar ao acusado punição desnecessária, desproporcional e, mais, pode ocasionar uma indevida dupla punição pelo mesmo fato.

O presente estudo tem como objetivo geral analisar a possibilidade de aplicação do instituto da detração penal nos casos em que o recolhimento domiciliar cumulado com o monitoramento eletrônico for utilizado como medida cautelar. Para tanto, será feita análise do tema medidas cautelares penais, especialmente do recolhimento domiciliar e do monitoramento eletrônico. Será conceituado o instituto da detração penal e sua modificação pela Lei n ${ }^{\circ} 12.736$, de 30 de novembro, de 2012, que alterou o CPP e possibilitou que a detração seja considerada na sentença condenatória para fixação do regime inicial de cumprimento de pena e, ainda, serão analisadas alterações trazidas pela Lei 12.403/2011.

A análise ocorrerá mediante o estudo de pesquisa bibliográfica, como doutrinas e leis atinentes ao caso, para verificar se a proposta é adequada diante da proibição do bis in idem e dos princípios da proporcionalidade e da dignidade da pessoa. 


\section{MEDIDAS CAUTELARES DIVERSAS DA PRISÃO}

O Código de Processo Penal brasileiro é de 1941 e foi inspirado na legislação processual italiana produzida na década de 30, em pleno regime fascista, de forma que a prisão em flagrante significava presunção de culpabilidade (OLIVEIRA, 2014, p. 148). Nesse contexto, no processo penal a prisão era regra e a liberdade, exceção.

Segundo Bianchini et al. (2012, p. 21), poucas eram as possibilidades de liberdade provisória, "a prisão convertia-se automaticamente em prisão cautelar, sem a necessidade de o juiz ratificá-la".

Assim, "a violação do princípio da inocência era mais do que evidente. [...] Antecipava-se o juízo de culpabilidade. Antecipava-se o cumprimento da pena.” (BIANCHINI et al., 2012, p. 21). Portanto, o Código de Processo Penal não se preocupava com a cautelaridade da prisão antes do trânsito em julgado.

Com a evolução do ordenamento, o codex, passou a admitir duas hipóteses de prisão cautelar: a temporária e a preventiva. Nesse sentido, o artigo 231, in verbis:

Art. 283. Ninguém poderá ser preso senão em flagrante delito ou por ordem escrita e fundamentada da autoridade judiciária competente, em decorrência de sentença condenatória transitada em julgado ou, no curso da investigação ou do processo, em virtude de prisão temporária ou prisão preventiva. (Redação dada pela Lei $\mathrm{n}^{\circ}$ 12.403, de 2011).

$\S 10$ As medidas cautelares previstas neste Título não se aplicam à infração a que não for isolada, cumulativa ou alternativamente cominada pena privativa de liberdade. (Incluído pela Lei n ${ }^{\circ} 12.403$, de 2011).

$\S 20$ A prisão poderá ser efetuada em qualquer dia e a qualquer hora, respeitadas as restrições relativas à inviolabilidade do domicílio. (Incluído pela Lei ${ }^{\circ} 12.403$, de 2011) (BRASIL, 2011).

A prisão cautelar é aquela que ocorre na fase investigatória ou no curso do processo, antes do seu trânsito em julgado, só podendo ser aplicada quando incabíveis as medidas cautelares diversas à prisão (GOMES FILHO, 2011, p. 25).

Távora e Alencar (2012, p. 642) complementam aduzindo que as prisões temporária e preventiva são espécies de prisão cautelar, que tem como gênero a medida cautelar.

No Direito Processual Civil brasileiro, Theodoro Júnior (2012, p. 505) explica que a função cautelar é de proteger provisoriamente os elementos processuais que, "na duração ou demora do processo principal, enfrentar situações de risco de dano, por conduta de um dos litigantes ou por evento ocasional". Nesse sentido:

Mas esta função não consiste em antecipar a solução da lide para satisfazer prematuramente o direito material subjetivo em disputa no processo principal. $\mathrm{O}$ que se obtém no processo cautelar, e por meio de uma medida cautelar, é apenas a prevenção contra o risco de dano imediato que afeta o interesse litigioso da parte e que compromete a eventual eficácia da tutela definitiva a ser alcançada no 
processo de mérito (THEODORO JÚNIOR, 2012, p. 506).

As medidas cautelares também estão previstas no direito processual penal brasileiro e, assim como no direito processual civil, têm o objetivo de assegurar o resultado do processo principal. Porém, ao contrário do processo civil que tem como pressupostos o fumus boni iuris e o periculum in mora, no processo penal os requisitos são o fumus commissi delicti e o periculum libertatis.

O fumus commissi, ou seja, "fumaça do cometimento de um fato punível" se exterioriza na prova da existência do crime e indícios de autoria (GOMES FILHO, 2012, p. 31). Enquanto o periculum libertatis diz respeito ao perigo que decorre do estado de liberdade do agente, podendo causar danos à ordem pública, funcionando como conveniência da instrução criminal, para assegurar a aplicação da lei penal.

Conforme Aury Lopes Júnior (2014, p. 806), a "ação cautelar" é inexistente no Código de Processo Penal, não havendo o que se falar em processo penal cautelar. O que se tem são "medidas cautelares penais", a serem tomadas no curso da investigação preliminar, processo de conhecimento ou no processo de execução.

A esse respeito, as palavras de Guilherme de Souza Nucci, sobre a medida cautelar no processo penal:

A medida cautelar, tal como estampada no Código de Processo Penal, é um instrumento restritivo da liberdade, de caráter provisório e urgente, diverso da prisão, como forma de controle e acompanhamento do acusado, durante a persecução penal, desde que necessária e adequada ao caso concreto. Estão previstas no art. 319 do CPP. (NUCCI, 2012, p. 29).

Para que sejam decretadas medidas cautelares do art. 319, do CPP, deve-se obedecer aos requisitos previstos no art. 282 , I e II, CPP:

Art. 282. As medidas cautelares previstas neste Título deverão ser aplicadas observando-se a:

I - necessidade para aplicação da lei penal, para a investigação ou a instrução criminal e, nos casos expressamente previstos, para evitar a prática de infrações penais;

II - adequação da medida à gravidade do crime, circunstâncias do fato e condições pessoais do indiciado ou acusado. (BRASIL, 1941).

Sobre a aplicação das medidas previstas no art. 319 do CPP, o STF elucida que, de acordo com o art. 282, $\S 6^{\circ}, \mathrm{CPP}$, a prisão é a ultima ratio das medidas cautelares, e o juízo competente deve observar sua aplicabilidade ao caso concreto. (STF, $2^{\text {a }}$ Turma, Habeas Corpus 106.446 / SP, Rel. Min. Cármen Lúcia, DJ 11.11.2011, p. 2). Caso contrário, o magistrado deverá avaliar quais medidas alternativas à prisão deverão ser aplicadas ao caso em análise.

Para muitos doutrinadores a implementação do art. 319 no CPP, pela Lei 12.403/2011 pode significar uma mudança na mentalidade jurídica brasileira, e ainda no quadro prisional do país. 
Como aduz Nucci, muitos acusados que merecem algum tipo de restrição em sua liberdade, não precisam necessariamente seguir para o cárcere, em regime fechado. "Por vezes, medidas alternativas serão suficientes para atingir o desiderato de mantê-lo sob controle e vigilância" (NUCCI, 2012, p. 104).

A referida Lei 12.403/2011 é fruto do Projeto de Lei no 4.208, apresentado em 12 de março de 2001, que tramitou no Congresso Nacional por dez anos até a vigência e efetiva alteração de dispositivos do CPP, relativos à prisão, medidas cautelares e liberdade (BRASIL, 2001).

\subsection{Lei 12.403/2011}

A principal alteração trazida pela referida lei trata da revisão das regras cautelares penais apresentadas no art. 319 do CPP.

Para Bottini (2011):

A aprovação da Lei 12.403/11 demonstra que a discussão serena e racional de propostas legislativas produz bons resultados. O texto final é produto de longos debates acadêmicos e parlamentares, iniciados em 2001, com a apresentação da primeira proposta de revisão das regras sobre cautelares penais por uma comissão de juristas presidida pela professora Ada Pellegrini. Anos depois, o projeto foi apontado como uma das quatro propostas mais importantes para a reforma processual penal pelo $1^{\circ}$ Pacto por um Judiciário mais Rápido e Republicano, firmado pelos três Poderes da República em 2004. Passado mais um longo período, a proposta foi finalmente aprovada e sancionada na integra.

Para Nucci (2012, p. 9), a referida lei atendeu a um clamor majoritário da doutrina e jurisprudência pátria, "razão pela qual merece particular atenção por parte dos operadores do Direito, para que seus preceitos sejam, realmente, aplicados".

Sobre a implementação da Lei 12.403/2011, o legislador deu nova disciplina às medidas cautelares no processo penal, modificando provimentos relativos à liberdade de locomoção do agente (LIMA, 2014, p. 774).

Durante anos e anos, nosso sistema processual penal ofereceu ao magistrado apenas duas opções de medidas cautelares de natureza pessoal: prisão cautelar ou liberdade provisória, lembrando que, antes do advento da Lei ${ }^{\circ} 12.403 / 11$, esta medida de contracautela só podia ser concedida àquele que fora anteriormente preso em flagrante (LIMA, 2014, p. 775).

Para Lopes Júnior (2014, p. 624), a maior inovação da Lei 12.403/2011 foi a "criação de uma polimorfologia cautelar, ou seja, o estabelecimento de medidas cautelares diversas da prisão, nos termos do art. 319, rompendo com o binômio prisão-liberdade até então vigente".

Bianchini et al. (2012, p. 23) aduzem que "as medidas cautelares alternativas à prisão são medidas descarcerizadoras, que visam evitar o encarceramento do agente antes da sentença final transitada em julgado.": 
Várias são as medidas cautelares colocadas, agora, à disposição do juiz (art. 319 do CPP). Elas contam com a primazia sobre a prisão cautelar (sobre o encarceramento). A prisão cautelar deve ocupar sua posição de extrema ratio da ultima ratio, que é o direito penal (cf. art. 282, parágrafo $6^{\circ}$, do CPP) (BIANCHINI et al., 2012, p. 23).

Importante salientar que o $\S 1^{\circ}$ do art. 282, do CPP, estabelece que as medidas cautelares poderão ser aplicadas isolada ou cumulativamente. Para tanto, o juiz vai analisar o caso concreto, adotando tais medidas acautelatórias quando houver compatibilidade entre elas. Segundo Brasileiro de Lima (2014, p. 791), é o caso do recolhimento domiciliar no período noturno e nos dias de folga, cuja aplicação pode ser cumulada ao monitoramento eletrônico para se obter maior eficácia em seu cumprimento.

Além disso, Lopes Júnior (2014, p. 630) destaca que, ainda que fundadas no senso de responsabilidade e autodisciplina do imputado, tais medidas, quando cumuladas, podem assegurar maior eficácia, podendo ser chamada como "medida secundária", para reforçar os incisos I (comparecimento periódico em juízo, no prazo e nas condições fixadas pelo juiz, para informar e justificar atividades) e II (proibição de acesso ou frequência a determinados lugares quando, por circunstâncias relacionadas ao fato, deva o indiciado ou acusado permanecer distante desses locais para evitar o risco de novas infrações) do art. 319, CPP, por exemplo.

Dentre as hipóteses de medidas cautelares que demonstram eficiência quando aplicadas de forma cumulada, estão o recolhimento domiciliar noturno (V, art. 319, CPP) e monitoramento eletrônico (IX, art, 319, CPP), pois sua aplicação conjunta reforça a possibilidade de fiscalicação da pessoa, seja ela investigada ou acusada.

\section{RECOLHIMENTO DOMICILIAR NOTURNO}

O inciso V do art. 319 do CPP prevê o recolhimento domiciliar, no período noturno e nos dias de folga, como medida cautelar diversa da prisão, quando o investigado ou acusado tenha residência e trabalho fixo. A nova medida cautelar repete a figura do regime aberto, na modalidade de prisão albergue domiciliar. (NUCCI, 2012, p. 107).

Para que seja aplicada, deve considerar a qualidade do investigado ou acusado, que deve respeitar as regras da restrição imposta e, ainda, ter residência e trabalho fixos, condições objetivas para sua aplicação (ATILA, 2011).

Para Eugênio Pacelli de Oliveira (2011, p. 265):

Trata-se de providência que, em principio, deveria se limitar à substituição de prisão em flagrante, nas hipóteses em que não seja ainda adequada e necessária decretação da prisão preventiva (art. 312, CPP), ou, que o fato não se enquadre nas circunstâncias do art. 313, CPP, requisitos específicos daquela modalidade de prisão. 
Segundo Lopes Júnior (2014, p. 630-631), tal medida cautelar pode servir a diferentes fins, desde a redução do risco de fuga, tutela da prova e, até mesmo, escopos metacautelares, como prevenção especial e geral.

Para Nucci, o recolhimento domiciliar, como medida punitiva e sem a devida fiscalização, torna-se fator de descrédito para o sistema penal. Todavia, soa razoável como medida cautelar, pois "não deixa de figurar como constrangimento à liberdade individual, em especial ao acusado, presumidamente inocente até decisão condenatória definitiva.” (NUCCI, 2014, p. 650).

Eugênio Pacelli de Oliveira (2011, p. 510) afirma que tal medida não se trata de "prisão domiciliar", cabível somente como substituto à prisão preventiva e nas hipóteses previstas no art. 318 do CPP. Ainda sobre a diferença entre o "recolhimento domiciliar" do art. 319 do CPP e a “prisão domiciliar" prevista no art. 318 do CPP, discorre Nucci (2014, p. 650):

[...] a prisão prevista pelo art. 318 é fruto do cumprimento da preventiva, destinandose a réus em situações excepcionais. Ademais, a prisão domiciliar abrange as 24 horas do dia, somente podendo o sujeito deixar a casa com autorização expressa e prévia do magistrado. O recolhimento domiciliar envolve apenas o período noturno e os dias de folga, voltando-se ao acusado que tenha residência e trabalho fixos. Quem é inserido em prisão domiciliar tem a preventiva decretada; quem se encontra em recolhimento domiciliar tem medida cautelar diversa da prisão imposta. $\mathrm{O}$ não cumprimento da prisão domiciliar importa em mera transferência do réu para o cárcere fechado; o não seguimento do recolhimento domiciliar implica, como última solução, a decretação da preventiva.

Ademais, também não se trata do recolhimento domiciliar previsto no art. 117 da LEP, em que tal hipótese só sera admitida quando se tratar de condenados maiores de 70 anos, condenados acometidos de doença grave, condenada com filho menor deficiente físico ou mental ou, ainda, condenada gestante.

Já sobre sua aplicação, Nucci (2012, p. 107) elucida que se adequa a crimes em geral, evitando que o acusado mantenha contato social, quando fora do trabalho.

Quando aplicada cumulada a outra cautelar, como aduz Lopes Júnior (2014, p. 630), o juiz deverá atentar para a proporcionalidade, "evitando a excessiva gravosidade para o réu das restrições, mantendo-se nos limites da necessidade".

Nestes termos, o recolhimento domiciliar noturno poderá, por exemplo, ser aplicado cumulado ao monitoramento eletrônico, hipótese em que o acusado poderia sair para trabalhar e teria o seu trajeto fiscalizado pelo uso da tornozeleira, permitindo vigilância contínua e verificação do regular cumprimento das medidas cautelares.

\section{MONITORAMENTO ELETRÔNICO}

Sobre o monitoramento eletrônico, as palavras da juíza Maria Lúcia Karam: 
O monitoramento eletrônico não é apenas a ilegítima intervenção no corpo do indivíduo condenado, a desautorizada invasão de sua privacidade, a transformação do seu antes inviolável lar em uma quase-prisão, em uma filial daquela que era a instituição total por excelência. [...] O controle vai muito além. Espraiase pelos mais diversos espaços privados e pelo espaço público. Ultrapassa os limites do sistema penal regular. Atinge não apenas os selecionados indivíduos que, processados pela justiça criminal, cumprem o papel de 'criminosos' (não necessariamente apenas os efetivamente condenados, bastando que figurem como réus em um processo penal condenatório) (KARAM, 2007, p. 4-5).

De fato, o controle proporcionado pelo monitoramentro eletrônico ultrapassa os limites do sistema penal regular, todavia, tal ferramenta permite que o condenado não seja retirado abruptamente do seu meio social. Seus direitos ficariam limitados, porém permaneceria o convívio com a sociedade, de forma que não seria dessocializado, mas sim educado a não praticar novamente o fato cometido. (GRECO, 2016).

O monitoramento eletrônico pode ser aplicado nas infrações penais em que seja viável a permanência do condenado fora da prisão, nos casos em que as infrações penais não possuam gravidade extrema. Neste caso, o réu ficaria limitado a um local predeterminado, contudo, sem ser privado de sua liberdade (GRECO, 2016).

No Brasil, a discussão legislativa sobre a possibilidade de implementação de monitoração eletrônica teve início no ano 2000 (NUCCI, 2011, p. 23). Porém, somente 10 anos depois, foi introduzida no direito brasileiro, com a publicação da Lei $n^{\circ} 12.258$, de 15 de junho, de 2010, que alterou a Lei n 7.210 , de 11 de julho, de 1984 (Lei de Execuções Penais), tratando do tema especificamente no art. 146-B.

Art. 146-B. O juiz poderá definir a fiscalização por meio da monitoração eletrônica quando: (Incluído pela Lei n ${ }^{\circ} 12.258$, de 2010)

I - (VETADO); (Incluído pela Lei ${ }^{\circ} 12.258$, de 2010)

II - autorizar a saída temporária no regime semiaberto; (Incluído pela Lei ${ }^{\circ}$ 12.258, de 2010)

III - (VETADO); (Incluído pela Lei no 12.258, de 2010)

IV - determinar a prisão domiciliar; (Incluído pela Lei $\mathrm{n}^{\circ}$ 12.258, de 2010)

V - (VETADO); (Incluído pela Lei n ${ }^{\circ} 12.258$, de 2010)

Parágrafo único. (VETADO). (Incluído pela Lei n 12.258, de 2010) (BRASIL, 1984).

Enquanto medida cautelar, a hipótese do monitoramento eletrônico virou opção nos casos de medida diversa da prisão cautelar, com a redação da Lei que trata das Medidas Cautelares Penais em 2011, que alterou o Código de Processo Penal, e incluiu o art. 319. (BRASIL, 1941).

Guilherme de Souza Nucci (2012, p. 110) explica que o monitoramento eletrônico servirá para fiscalizar os passos do indiciando ou acusado, de forma que o juiz pode deixar de decretar a prisão preventiva, optando pelo meio eletrônico e, com isso, reduzindo a população carcerária.

Nestes termos, são as palavras de Lopes Júnior (2014, p. 624): 
Neste novo dispositivo legal consagra-se o monitoramento como medida cautelar, em que a possibilidade de vigilância ininterrupta serve como tutela para o risco de fuga e a prática de novas infrações. Ao permitir o permanente controle sob a circulação do acusado, também serve de útil instrumento para dar eficácia às demais medidas cautelares diversas, tais como a proibição de acesso ou frequência a determinados lugares, a proibição de ausentar-se da comarca ou país e o recolhimento domiciliar. Cumpre assim, diferentes dimensões de tutela cautelar.

Segundo Godói (2011), a medida possibilita a fiscalização da determinação de recolhimento domiciliar, ou da proibição de acesso ou frequência a determinados lugares, desautorizando a prisão preventiva quando se mostrar suficiente para a realização dos objetivos estabelecidos no art. 282, I, do CPP, de garantia de aplicação da lei penal, conveniência da investigação ou da instrução criminal e, nos casos expressamente previstos, de prevenção contra a prática de novas infrações penais.

A monitoração, por sua abrangência, é medida que se presta a todas as finalidades das cautelares - garantia da ordem pública, da instrução criminal e da aplicação da lei penal - já que permite ao judiciário verificar se o preso continua praticando infrações penais ou se apresenta indícios de fuga (BIANCHINI, 2012, p. 199).

Nucci (2012, p. 110) destaca que $a$ "lei processual não fornece parâmetros para a aplicação dessa nova medida cautelar, ficando ao critério de cada magistrado regular suas condições e limites.” Aduz, ainda, que será necessário implantar centrais de monitoração eletrônica em várias regiões para que esse instrumento seja efetivamente utilizado como medida cautelar e questiona se haverá verba e interesse suficientes para instalar essas centrais de monitoração, a fim de permitir que todos os juízes brasileiros apliquem tais medidas.

Não obstante as polêmicas supramencionadas, importante reforçar que a tornozeleira, enquanto medida cautelar, implica restrição de direito antes do decreto condenatório e, portanto, precisa ser analisada face ao instituto da detração, inclusive, sob pena de ferir o princípio da proporcionalidade por meio da aplicação excessiva de pena, causando, ao condenado, danos maiores do que o indispensável para a proteção do interesse público (GOMES, 2003, p. 35).

\section{DETRAÇÃO PENAL}

O instituto da detração penal está previsto no artigo 42 do Código Penal:

Art. 42 - Computam-se, na pena privativa de liberdade e na medida de segurança, o tempo de prisão provisória, no Brasil ou no estrangeiro, o de prisão administrativa e o de internação em qualquer dos estabelecimentos referidos no artigo anterior. (BRASIL, 1940).

Bitencourt (2003, p. 201) ensina: “através da detração penal permite-se descontar, na pena 
ou na medida de segurança, o tempo de prisão ou de internação que o condenado cumpriu antes da condenação."

Discorre Nucci sobre a aplicação da LEP ao preso provisório:

[...] em caso de condenação definitiva, aplicar-se-á a detração (art. 42, CP), isto é, o desconto na pena privativa de liberdade ou na medida de segurança do tempo de prisão provisória ou de internação, o que resulta na absorção da prisão cautelar, pela prisão definitiva, tornando um só o período computado. Assim, todos os direitos do preso são, igualmente e quando compatíveis com a natureza da sua prisão, assegurados ao acusado cautelarmente detido (NUCCI, 2011, p. 101).

A prisão provisória a que se refere à lei é a prisão processual, que pode ocorrer em virtude de atuação em flagrante de delito, de prisão temporária, de prisão preventiva, de sentença de pronúncia e de decisão condenatória recorrível, ou seja, em todas as hipóteses em que o criminoso é recolhido à prisão antes da prolação da sentença condenatória definitiva que autoriza a execução da pena (MIRABETE, 2008, p. 266).

O art. 66, III, c, da LEP diz que compete ao juiz da Execução decidir sobre a detração da pena, todavia, sua aplicação se dará pelo juiz da condenação, quando da dosimetria da pena, momento em que será abatido o período de prisão processual (PINTO, 2013). Nas palavras de Capez, a detração é incidente processual, prevista referido artigo:

Trata-se de incidente de execução, previsto no art. 66, III, c, da LEP. Após o trânsito em julgado da sentença condenatória, será expedida guia de recolhimento para dar início ao processo de execução. Em seguida, procede-se ao cálculo de liquidação das penas impostas em diferentes processos, somando-as (concurso material) ou unificando-as (crime continuado ou concurso formal, conforme o caso). Obtido o total a ser cumprido, desconta-se o tempo de prisão provisória. Trata-se de uma simples operação aritmética de subtração: pena menos prisão provisória (CAPEZ, 2011).

Tal aplicação evita que uma pessoa fique presa mais tempo do que a pena imposta na sentença condenatória, já que a prisão provisória não é punição, mas instrumento auxiliar da tutela jurisdicional. Portanto, nos casos que a prisão preventiva for decretada, esse tempo será descontado em pena privativa de liberdade, desviando-se de uma dupla apenação pelo mesmo fato (CAPEZ, 2011).

Esse autor reforça que a detração é matéria de competência exclusiva do juízo da execução, não cabendo, portanto, ao juiz da condenação aplicá-la desde logo, para poder fixar um regime pena mais favorável ao acusado, pois, estaria se dando início ao cumprimento de pena em dado regime antes de se conhecer a pena definitiva (CAPEZ, 2002, p. 388).

A Lei $n^{\circ}$ 12.736, de 30 de novembro, de 2012, deu nova redação ao art. 387 do CPP, para a detração ser considerada pelo juiz que proferir a sentença condenatória, ou seja, pelo magistrado que condenar o acusado (BRASIL, 2012).

Então, o juiz na sentença condenatória, passa a ter um novo dever, ao analisar se o réu 
ficou preso provisoriamente, administrativamente, ou internado no curso do processo e, caso uma das opções seja positiva, esse tempo deverá ser descontado pelo magistrado, da pena imposta ao condenado.

Segundo Marivaldo Pereira (2013) a alteração na lei autoriza o juiz a realizar o desconto dos dias cumpridos provisoriamente já na sentença penal condenatória e ajustar o regime inicial de cumprimento da pena, permitindo que o indivíduo - cujo direito somente seria reconhecido meses depois pelo juiz da execução penal quando já protocolada a guia de recolhimento - possa dele desfrutar imediatamente.

Portanto, conforme esse autor, a novidade legislativa:

Significa dizer que a recente lei antecipa o reconhecimento de direito legalmente assegurado sem a necessidade de esperar a burocracia do sistema de justiça, porquanto do sentenciado será, forçosamente, descontado o tempo de prisão provisória ou de internação, reforçando a garantia fundamental de individualização da pena, presente no artigo $5^{\circ}$, inciso XLVI, da Constituição Federal (PEREIRA, 2013).

Importante esclarecer que a detração não se trata de ampliação de benefícios, nem de progressão de regime, mas de viabilização do reconhecimento de direito que impede o indesejável bis in idem, bem como colabora para a análise da proporcionalidade do Direito Penal.

Enquanto estava em aprovação, a referida modificação foi muito criticada. Alguns doutrinadores entendiam que sua implementação influenciaria o magistrado, que ficaria tendencioso a aplicar uma pena mais alta na sentença condenatória, para evitar uma pena mais branda ao acusado em virtude da detração penal, no intuito de evitar suposto sentimento de injustiça (SILVA, 2016).

Ainda sobre o tema, o autor entende que a alteração era realmente necessária, pois, a referida lei se origina no sofrimento, desnecessário e injusto, atribuído ao preso, obrigando-o a cumprir pena de prisão além do prazo estabelecido pela justiça (SILVA, 2016).

Seu objetivo foi acelerar a concessão dos benefícios da execução penal ao condenado, em especial quanto ao regime de cumprimento de pena (CAVALCANTE, 2012):

Nesse sentido, segundo Marivaldo Pereira (2013):

A implementação da lei se deu com o propósito de racionalizar o sistema de execução penal, fornecendo mecanismos eficazes ao reconhecimento célere de direitos e benefícios, e evitar o encarceramento desnecessário de pessoas cuja situação jurídica já lhes permite maior aproximação da liberdade, a nova legislação funcionará como mais um mecanismo de acesso à Justiça da população carcerária.

Mas, talvez, o principal objetivo da detração seja garantir o princípio do ne bis in idem, que determina que ninguém será punido duas vezes pelo mesmo fato (LOPES JÚNIOR, 2014, p. 821). Pois, neste caso, o investigado, ou acusado, que permaneceu sob recolhimento noturno, cumulado 
ao monitoramento eletrônico, já teve seu direito de locomoção restrito e, portanto, não poderá ser apenado em duplicidade caso receba pena privativa de liberdade ao final do processo.

Todavia, o legislador não tratou de adequar a possibilidade de detração penal, quando da implementação da Lei 12.403/2011, principalmente no que diz respeito às hipóteses do art. 319 do CPP.

\section{HIPÓTESE DE DETRAÇÃO NAS MEDIDAS CAUTELARES}

A Lei 12.403/2011 nada disse quanto à possibilidade de detração do tempo de cumprimento das medidas cautelares diversas da prisão, do total de pena aplicado ao final do processo penal.

Em análise preliminar, os doutrinadores concordam quando se trata da aplicação de pena semelhante à medida cautelar aplicada no processo, como preceitua Brasileiro de Lima (2014, p. 802): "havendo semelhança e homogeneidade entre a medida cautelar aplicada no curso do processo e a pena imposta ao acusado na sentença condenatória irrecorrível, é plenamente possível a detração."

No mesmo sentido, Nucci (2012, p. 110) elucida:

Quanto à possibilidade de detração, manifestamo-nos em outras de nossas obras, pela possibilidade de se utilizar a medida cautelar alternativa para tal efeito se $e$ somente se a penal aplicada for idêntica à cautelar experimentada pelo acusado. Exemplo: aplicada a medida cautelar de proibição de frequentar lugares, por óbvio, há que se operar a detração. Afinal, o réu não deve cumprir duas vezes a mesmíssima restrição. Seria um inadmissível bis in idem.

Todavia, quando a pena aplicada for mais gravosa do que a medida cautelar, os autores divergem quanto à possiblidade de aplicação da detração.

Para Renato Brasileiro de Lima (2014, p. 802), no que diz respeito às medidas cautelares do art. 319 do CPP, seria inviável a aplicação da detração, pois tais hipóteses não representam restrição absoluta à liberdade e guardam homogeneidade com uma possível pena de prisão ao final do processo.

Assim sendo, mesmo se a medida aplicada configurar restrição de direito, seguindo-se pena privativa de liberdade, em qualquer regime, não existe possibilidade de aplicação da detração (NUCCI, 2012, p. 110).

Nestes termos, também é o entendimento de Capez (2011), ao reforçar que o caput do art. 319 do CPP diz, expressamente, que tais medidas cautelares são diversas da prisão e, portanto, não se confundem.

No sentido contrário, Eugênio Pacelli de Oliveira (2011, p. 511) defende a detração para a hipótese do recolhimento noturno:

$\mathrm{E}$, como se trata de medida de inegável gravidade, limitativa da liberdade de locomoção, ainda que somente em período noturno e nas folgas do trabalho, 
pensamos que o tempo de seu cumprimento deve ser levado à conta da detração da pena, como se tratasse de verdadeira prisão provisória, nos termos, portanto, do art. 42, do Código Penal. E nem se diga que o desconto do tempo na pena seria incabível em razão da liberdade para o trabalho.

E o autor completa, lembrando que a ressocialização do condenado é um dos principais objetivos da execução da pena no Brasil e, portanto, o trabalho deve ser sempre incentivado, principalmente quando não oportunizado pelo Estado (OLIVEIRA, 2011, p. 511).

Para Cury (2014), de fato, o recolhimento domiciliar do art. 319 do CPP não pertence à espécie de prisão cautelar, mas, "importa na efetiva privação da liberdade do indivíduo, em caráter parcial”. Sua única diferença para a prisão domiciliar dos artigos 317 e 318 do CPP - hipótese em que há detração da pena -, é o tempo de privação de liberdade imposto ao investigado ou acusado, logo, deverá ter seu tempo computado na detração, em respeito aos princípios da igualdade, proporcionalidade e razoabilidade, pois, do contrário, implicaria no bis in idem, vedado em nosso ordenamento penal.

No que diz respeito ao monitoramento eletrônico, Pierpaolo Cruz Bottini (2011) aduz que "parece inadequado" que lei não explicite desconto de pena para os casos em que o réu for submetido a essa cautelar durante a instrução: "Se a detração da prisão tem por fundamento o principio da equidade e a vedação ao bis in idem, deve o instituto ser estendido a qualquer hipótese de intervenção do Estado em direitos do cidadão“.

$\mathrm{E}$, ao que diz respeito à restrição ao direito de locomoção imposta ao usuário do monitoramento eletrônico antes da sentença condenatória, Delmanto Júnior, citado por MENEZES (2012) enfatiza: "há de efetuar-se a detração desse lapso temporal, como forma razoável de compensação em face dos gravames consequentes do castigo antecipado".

No entanto, a omissão da hipótese de detração para o monitoramento eletrônico, enquanto medida cautelar distinta da prisão, como elucida Bottini, não impede sua aplicação pelo magistrado que, por analogia, pode beneficiar o réu:

Caso a cautelar e a pena tenham naturezas distintas - como na hipótese da cautelar de prisão domiciliar e a pena de prisão em regime fechado - o tempo descontado poderá ser o mesmo, mas é possível construir pela jurisprudência uma formula que permita deduzir proporcionalmente - com base na razoabilidade - algo da sanção para detrair a cautelar aplicada (BOTTINI, 2011).

Ainda que não seja este o caso, Renato Brasileiro de Lima (2014, p. 803) reforça que parece extremamente desarrazoado que o acusado, sujeito a uma medida extremamente gravosa como o monitoramento eletrônico, não tenha nenhum beneficio "até mesmo como forma de compensação decorrente dos gravames inerentes a esse castigo antecipado", e questiona se seria possível simplesmente desconsiderar o lapso temporal por ocasião do cumprimento do tempo de prisão penal.

E o mesmo autor (2014, p. 803) trás à luz, uma possível solução para a questão, quando 
sugere que a detração seja trabalhada em critério semelhante ao da remissão (art. 126 da LEP). Assim, o autor sugere que para cada 03 (três) dias de cumprimento da medida cautelar, seja descontado 01 (um) dia de pena do agente:

Esse critério de remição, todavia, deve guardar relação com a gravidade da medida cautelar diversa da prisão. Assim, se a utilização do monitoramento eletrônico por 3 (três) dias pode dar ensejo a um dia a menos de prisão, certamente há de ser pensado outro critério para medidas cautelares menos gravosas (LIMA, 2014, p. 803).

Fato é que urge ao judiciário encontrar a interpretação necessária para o completo aproveitamento dos benefícios que a Lei 12.403/11 oferece, inclusive, como solução da superlotação nos presídios brasileiros. E, diante da omissão do legislador no que diz respeito à hipótese de detração face as medidas cautelares diversas da prisão, talvez, aplicá-la por analogia in bonam partem.

\section{CONSIDERAÇÕES FINAIS}

O presente artigo tratou de analisar a possibilidade de detração penal face ao recolhimento domiciliar noturno, cumulado com o monitoramento eletrônico, hipóteses de medidas cautelares diversas à prisão, apresentadas pela implementação da Lei 12.403/2011.

A implementação da referida lei demonstrou a intenção do legislador em encontrar soluções para o caos do sistema penitenciário brasileiro, em uma iniciativa que visa evitar e substituir a prisão cautelar.

Celas superlotadas, alto índice de reincidência dos presos e o elevado custo de manutenção de apenados e presídios são apenas alguns dos reflexos do evidente colapso do sistema carcerário.

Não obstante, a manutenção deste "modelo carcerário" desrespeita direitos humanos e fere o princípio da dignidade da pessoa humana apregoado pela nossa Carta Magna, Constituição da República Federativa do Brasil de 1988.

Nestes termos, desrespeita ainda, um dos objetivos basilares da execução penal brasileira, que é a ressocialização do condenado, pois, este indivíduo não recebe incentivo algum para buscar sua regeneração.

O recolhimento domiciliar noturno e o monitoramento eletrônico restringem a liberdade individual, impondo-lhe descomunal violência e, uma vez aplicadas antes do decreto condenatório, antecipam sim a condenação do sujeito.

Por outro lado, quando aplicadas de forma cumulada, o recolhimento noturno e o monitoramento eletrônico constituem uma opção ao magistrado, que tem condições de monitorar o investigado, acusado ou indiciado. Tal medida evita o encarceramento desnecessário e gera, inclusive, economia para o Estado ao evitar despesas com o preso encarcerado.

Assim, tendo em vista que as medidas cautelares da prisão domiciliar e do recolhimento 
domiciliar noturno, bem como do monitoramento eletrônico (artigos 318 e 319 do CPP), apesar de mais leves que a prisão cautelar, restringem o direito de ir e vir, não parece razoável concluir pela inadmissibilidade da detração penal.

Portanto, é viável que a jurisprudência construa, mesmo sem apoio legislativo específico, por analogia in bonam partem, admissível por força do art. $3^{\circ}$ do CPP, a hipótese da detração para tais medidas cautelares e, ainda, defina em que medida serão aplicadas, atendendo-se à proporcionalidade.

Evidente que o sentenciado que aguardou julgamento submetido a recolhimento domiciliar noturno, e, ainda, com utilização de monitoramento eletrônico, fará jus a abatimento do período que teve sua liberdade restringida no cômputo da pena a cumprir, para evitar bis in idem.

De modo contrário, o condenado seria apenado duas vezes em razão de um mesmo fato, a primeira ao ter sua liberdade restrita pelo recolhimento noturno e uso da tornozeleira e, novamente, ao cumprir a pena privativa de liberdade definitiva.

Nesses termos, atendendo-se a uma necessária leitura constitucional de todos os institutos de Direito Penal e de Processo Penal, conclui-se pela admissibilidade da detração penal ser aplicada não somente com base no tempo de prisão cautelar, mas também em casos de medidas cautelares diversas da prisão, que afetem a liberdade da pessoa. Trata-se de medida proporcional, adequada e que respeita a dignidade da pessoa, bem como evita o indesejável bis in idem.

\section{REFERÊNCIAS}

ATILA, Carlos Pierre de Lima. Breves comentários acerca das medidas cautelares

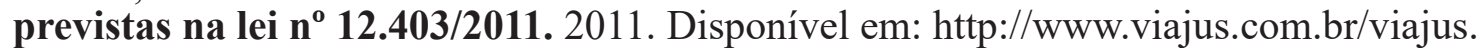
php?pagina=artigos\&id=4512\&idAreaSel=1\&seeArt=yes. Acesso em: 29 abr. 2016.

BIANCHINI, Alice; MARQUES, Ivan Luís; GOMES, Luiz Flávio; CUNHA, Rogério Sanches; MACIEL, Silvio. Prisão e medidas cautelares: comentários à Lei 12.403, de 04 de maior de 2011. 3. ed. São Paulo: Editora Revista dos Tribunais, 2012.

BITENCOURT, Cezar Roberto.Tratado de direito penal: parte geral, 1. 8 ed. São Paulo: Editora Saraiva, 2003.

BOTTINI, Pierpaolo Cruz. Nova lei peca nas chances de detração penal. 2011. Disponível em: http://www.conjur.com.br/2011-jul-01/nao-detracao-casos-cautelar-aplicada-distinta-prisao. Acesso em: 23 nov. 2018.

BRASIL. Decreto-Lei n. 2.848, de 7 de dezembro de 1940. Código Penal. Rio de Janeiro: Presidência da República, 1940. Disponível em: http://www.planalto.gov.br/ccivil_03/decretolei/del2848.htm. Acesso em: 23 nov. 2018.

BRASIL. Decreto-Lei n. 3.689, de 3 de outubro de 1941. Código de Processo Penal. Rio de Janeiro: Presidência da Republica, out. 1941. Disponível em: http://www.planalto.gov.br/ ccivil_03/Decreto-Lei/Del3689Compilado.htm. Acesso em: 23 nov. 2018.

BRASIL. Lei no 7.210, de 11 de julho de 1984. Institui a Lei de Execução Penal. Brasília: Presidência da República, 1984. Disponível em: http://www.planalto.gov.br/ccivil_03/leis/17210. htm. Acesso em: 23 nov. 2018.

BRASIL. Câmara dos Deputados. PL 4208/2001. Disponível em: http://www.camara.gov.br/ 
proposicoesWeb/fichadetramitacao?idProposicao=2655. Acesso em: 1 maio 2016.

BRASIL. Superior Tribunal Federal. Habeas Corpus 106.446 / SP, Rel. Min. Cármen Lúcia, DJ 11.11.2011, p. 2. 2011. Disponível em: http://www.stf.jus.br/arquivo/cms/ noticiaNoticiaStf/ anexo/Voto_HC_106446_Min._Dias_Toffoli.pdf. Acesso em: 25 nov. 2018.

CAPEZ, Fernando. Curso de processo penal. 8. ed. São Paulo: Editora Saraiva, 2002.

CAPEZ, Fernando. Prisão preventiva, medidas cautelares e detração penal. 2011. Disponível em: http://apamagis.jusbrasil.com.br/noticias/2852190/fernando-capez-prisao-preventivamedidas-cautelares-e-detracao-penal. Acesso em: 25 nov. 2018.

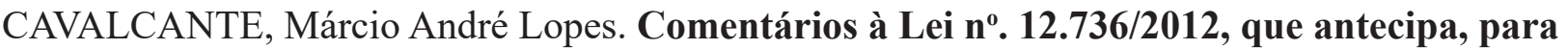
a sentença condenatória, o momento adequado para realizar a detração da pena. Disponível em: https://www.dizerodireito.com.br/2012/12/ comentarios-lei-127362012-que-antecipa.html. Acesso em: 25 nov. 2018.

CURY, Rogério. Detração penal e as medidas cautelares pessoais diversas da prisão - há compatibilidade? 2014. Disponível em: http://rogeriocury.jusbrasil.com.br/artigos/112256228/ detracao-penal-e-as-medidas-cautelares-pessoais-diversas-da-prisao-ha-compatibilidade. Acesso em: 23 nov. 2018.

CRUZ, Rogério Schietti. Prisão cautelar: dramas, princípios e alternativas. 3. ed. Salvador: Juspodivm, 2017.

GODOI, Antônio. LEI 12.403/11: comentários § Art. 319, CPP §. 2011. Disponível em: https:// pineapplelaws.wordpress.com/2011/07/10/1ei-12-40311-\%E2\%80\%93-comentarios-\%C2\%A7art-319-cpp-\%C2\%A7/. Acesso em: 23 nov. 2018.

GOMES, Mariângela Gama de Magalhães. O princípio da proporcionalidade no direito penal. São Paulo: Revista dos Tribunais, 2003.

GOMES FILHO, Antônio Magalhães. As nulidades no processo penal. 6 ed. São Paulo: Revista dos Tribunais, 2012.

GOMES FILHO, Antônio Magalhães. Medidas cautelares no processo penal: prisões e suas alternativas: comentários à lei 12.403, de 04.05.2011. São Paulo: Revista dos Tribunais, 2011.

GRECO, Rogério. Monitoramento eletrônico. Disponível em: https://rogeriogreco.jusbrasil. com.br/artigos/121819870/monitoramento-eletronico. Acesso em: 30 mar. 2016.

KARAM, Maria Lúcia. Monitoramento eletrônico: a sociedade do controle. Boletim IBCCRIM, São Paulo, ano 14, n. 170, jan. 2007.

LIMA, Renato Brasileiro de. Manual de processo penal. 2. ed. Salvador: Editora Juspodivm, 2014.

LOPES JÚNIOR, Aury. Direito processual penal. 11. ed. São Paulo: Editora Saraiva, 2014.

MENEZES, Dêvis Klinger. Prisão, medidas cautelares e detração penal. Conteúdo Jurídico, Brasilia-DF. maio 2012. Disponível em: http://www.conteudojuridico.com. br/?artigos\&ver $=2.37219 \& \mathrm{seo}=1>$. Acesso em: 15 abr. 2016.

MIRABETE, Julio Fabbrini. Manual de direito penal. 18. ed. São Paulo: Editora Atlas, 2008. NICOLITT, André. Manual de processo penal. 2. ed. Rio de Janeiro: Editora Elsevier, 2010. 
NUCCI, Guilherme de Souza. Princípios constitucionais penais e processuais penais. 2. ed., rev., atual. e ampl. São Paulo: Revista dos Tribunais, 2012

NUCCI, Guilherme Souza. Código penal comentado. 13. ed. São Paulo: Editora Revista dos Tribunais, 2014.

NUCCI, Guilherme de Souza. Prisão e liberdade: as reformas processuais penais introduzidas pela Lei no 12.403, de 4 de maio de 2011. 2. ed. São Paulo: Editora Revista dos Tribunais, 2011.

OLIVEIRA, Eugênio Pacelli de. Curso de processo penal. Rio de Janeiro, Lumen Juris, 2011.

OLIVEIRA, Eugênio Pacelli de. Curso de processo penal. 18. ed. São Paulo: Editora Atlas, 2014.

PEREIRA, Marivaldo. A nova lei de detração a sentença penal condenatória. Disponível em: http://www.conjur.com.br/2013-jan-22/lei-127362012-detracao-sentenca-penal-condenatoria. Acesso em: 1 abr. 2016.

PINTO, Ronaldo Batista. Provisória deve ser contada na progressão de regime. Disponível em: http://www.conjur.com.br/2013-jan-08/ronaldo-pinto-prisao-provisoria-contada-progressaoregime. Acesso em: 23 nov. 2018.

SILVA, Marcelo Rodrigues da. Detração penal: comentários à Lei 12.736 de 30 de novembro de 2012. Disponível em: http://marcelorodriguesdasilva56.jusbrasil.com.br/ artigos/121942264/ detracao-penal-comentarios-a-lei-12736-de-30-de-novembro-de-2012. Acesso em: 1 abr. 2016. TÁVORA, Nestor; ALENCAR, Rosmar Rodrigues. Curso de direito processual penal. 7. ed. Salvador: Juspodivm, 2012.

THEODORO JÚNIOR, Humberto. Curso de direito processual civil. 47. ed. Rio de Janeiro: Forense, 2012. v. 2.

Como citar: PEREIRA, Henrique Viana; MATTOS, Juliana Günther Fonseca de. Medida cautelar criminal de recolhimento domiciliar noturno cumulado com o monitoramento eletrônico e a aplicação da detração penal. Revista do Direito Público, Londrina, v. 14, n. 1, p. 65-82, abr. 2019. DOI: 10.5433/1980-511X2019v14n1p65. ISSN: 1980-511X.

Recebido em: 20/07/2016.

Aprovado em: 18/03/2019. 